\title{
酒神と神社 (18)
}

\section{加藤 百一}

\section{1.2 白山比咩神社}

北陸電鉄石川線加賀一の宮駅加ら東南へ $0.3 \mathrm{~km}$, 旧 官幣中社白山比咩神社は, 手取川が形成した右岸段丘, 石川県石川郡鶴来町常宮町の䙪蒼たる 杉木立の中に鎮 座する。祭神は白山比咩神・菊理媛神に, 伊衤諾尊・ 伊焋再尊を配妧する。

社伝によれば, 当社は霊峰白山のく祭の斎庭〉として 崇神天皇 7 年 ( 4 世紀後期) 飞創建されたといら。『延 喜式』（巻 10 , 神名下) の「加賀国石川郡」条に, 「白 山比咩神社」とあるのが当社で, 古くから白山本宮, 加 賀一の宮として篤敬され, また庶民からく白山さん>と して親しまれた北陸鎮護の名社である。な沶山山頂の 奥宮は 718 (養老 2 ) 年の創建で, 白山比咩神の神体山 として護持され，その境内地は 582 万坪 (1,921 万 $\mathrm{m}^{2}$ ) に及び，今日白山国立公園の中心をなしている。

当宮と菊酒との掛り合いは, 江戸後期の『周遊奇談』 の「つるぎの菊酒」の条に,

かがの国金沢城下ょり一里余り放れて，つるぎとい ふ町あり，ここに加賀国の一宮とて白山の社あり， ここに米屋といへる酒店にて作る名酒を, 菊酒とよ ぶなり, 但し菊酒の名儀は, 此の町に一河の流れあ りて, 是を白山川ともいふ, 此河水をもて作れる故 に,かく菊酒とよぶなり

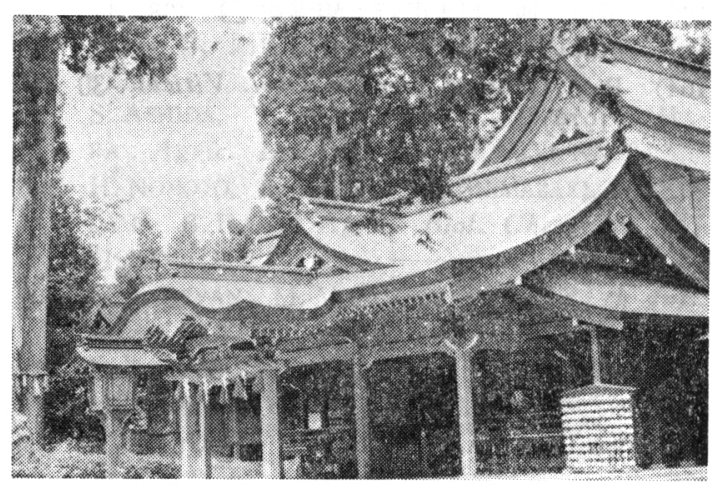

写真 6.2 白山比咩神社
とある記事から導びくことができる。

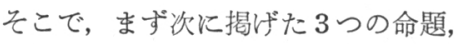

a）加賀の菊酒の系譜はどのようであろうか

b）どのような手法で菊酒が造られたか

c）菊酒の名称由来

を取り上げて，若干の考察を加えることにする。

(1) 加賀の菊酒の系譜

加賀の菊酒といえば, 誰もが室町後期の連歌師, 牡丹 花肖柏が「三愛記」(『群書類従』巻 21 所収) に,

さけはもろこし，南蛮のあぢはひを試み，九州のね

りぬき, 加州の菊花, 天野の出群なるをもとめ…… と録しているので知られている。「加州の菊花」酒は, 同 時代の学者, 一條兼良の『芦素往来』に,

酒八柳一荷, 加之天野, 南京之名物, 兵庫西宮

之旨酒, 及越前豊原, 加州宮越等, 相副瓶子並銚 子.......

などとあるように，加賀国臨川寺領として繁栄した河北 潟の河口, 宮越（現, 金沢市金石）から船積みされた。 宮越は北回り航路有数の港であったから，加賀の菊酒の 名は都をはじめ諸国に流布されるのも速やかであった。

加賀の菊酒は能「安宅」にも登場する。辨慶の機知 で, 安宅の関を無事脱出した義経主従は, そこから程近 い宿駅で，先ほどの非礼を詫びた関守から酒を進められ る場面がある。二十四世観世左近の謡本によれば,

怪しめらるな面々と, 辨慶に諫められて, この山蔭 の一宿りに, さらりと円居して, 所も山路の菊乃酒 を领まらよ

と詠まれている。これからが「面白や山水に」で始まる 辨慶の雄壮な男舞となり, 能のクライマックスとなる。

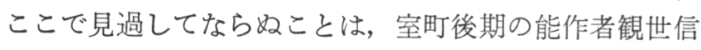
光が，能「安宅」に菊酒を詠いこんでいることで，それ 活ど都人の間でこの名が知られていたのであろう。ま た都から田舎への伝播も早かった。加賀の菊酒は,

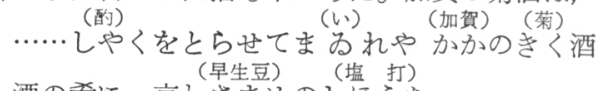
酒の看に京わさまめのし㙁うち 
などと, 中世末期以降, 安芸国の田植歌1) として早乙女 らが歌っていた。

室町後期, 加賀の菊酒が天下の銘酒としての名声を確 保するために，宮越が大さな役割を果したことは確しか であるが，といって，これらのことだけで，宮越が加賀 の菊酒の原産地であったとする決め手とはならない。

一方, 菊酒の原産地を白山本宮の抢膝元，鶴来とする 説2)もある。この出典は明らかではないが，たまたま室 町後期の『言継卿記』に,

阿仏坊菊酒皆々可申候申候, 皆々申候, 人数甘露寺 父子・中御門父子・四条父子・楖原 - 老父 - 予 - 氏 家・資直卿・阿仏坊・同弟平等坊等也，一ツ二ツ皆 々参候（大永七(1527)年四月十九日条）

とある。このことから当宮, つまり白山本宮の長老阿仏 坊と彼の弟平等坊が，加賀国から都へ上って菊酒を山科 言継に献じたことは，まぎれもない事実である。

このよらに, 加賀の菊酒が辇園領主や地頭への祝儀酒 となったことは, 能狂言「餅酒」の一節に,

是は加賀の国の御百姓でござる，毎年大烸日さかひ に持って上り，元朝に上頭へ捧ぐる実相坊の菊酒で 御座る

と録されていることからも確実性がある。

これらの資料から，菊酒が白山比咩神の鎮をる鶴来で 造られていたことは想像できても，鶴来を加賀の菊酒の 原産地とするのは早計である。といって，宮腰をそれに 当てるにはあまりにも傍証資料が少なすぎる。したがっ て, 宮腰の菊酒之鶴来の菊酒とは，系譜的に直接的なつ ながりがあったかどうかは不詳というほかはない。

（2） 菊酒の造法

菊酒は，元初期の『居家必要』に菊花の香を付与する 造り方が，また本邦では『御酒之旨記』の「菊酒日記」 に，宮中重陽宴の菊酒造りが見られる ${ }^{3)}$ が，加賀の菊酒 がこれら造法と同じであったかどらかは分からない。

江戸前期の『本朝食鑑』飞記載の肥後法は焼酎をべー スにした再成酒であり，同後期の『手造酒法』の菊酒は みりん法で, いずれも醸造酒ではないので，加賀の菊酒 とは全く異質の造法類型に属する。次に，同食鑑に掲載 された加賀法を取り上げる。同食鑑には，

一種用二菊潭水 - 造レ 酒, 賀州有二菊川 - 両岸多レ

菊, 至レ 秋黄花爛慢, 摘二 其花一汲二川流，併煮

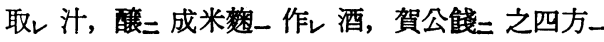
とある。つまり秋, 菊川の両岸に咲く菊花を摘みとり， この川水で煎じ，この煎じ汁を仕込水として米楼・蒸米 を掛け, 糖化・発酵したものが菊酒であるという。この 酒が，江戸の将軍家などに贈られたく加賀菊花酒〉であ るが，宮越の菊酒がこれと同じ造法であったかどうか，
傍証資料のないかぎり何ともいえない。

醸造法による菊酒造りは, 明末期の『本草綱目』に,

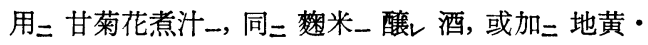

当帰・枸杞諸薬—亦佳

とあり,この菊酒は種々の漢方薬が使われていたことが 知られる。しかし, 加賀の菊酒は, 漢方薬添加の薬味酒 ではなかったことは確しかである。

（3）鶴来の菊酒の名称由来

1）鶴来所在の米屋で造った名酒が菊酒といわれたの は, この町の西側を流れる白山川の水で仕込まれたから という。この菊酒の名称由来に続いて, 同奇談には,

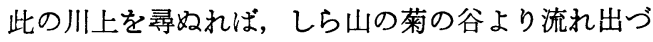
る水なり菊沢とむいら，この菊の谷は両岸一面に黄菊 也, 其露打のつから河水によくし流るるゆへ, 酒造 には無類の名水，和漢ともに寿を延ぶること世にし る所なり

とある。つまり『本朝食鑑』の菊川説話同様, 両岸に, 延命の効ありといら黄菊が咲く菊谷を水源とする白山川 の, この無類の水が酒造りに使われていたからと説明し ている。

2）汇戸後期の『奇談北国杖巡記』によれば, 加州金沢浅野河の水源に，白菊の淵といふ所あり， 四時ともに白菊咲きあひ……この川水に菊の滴り流 れこみて，薬の水なるとて，金沢の酒家に汲及運 び，善く是にて酒を製すれば……人々菊酒と称 とある。したがって，金沢の酒を菊酒と称したのは，水 源に, 白菊の咲き乱れる白菊淵という仙境をもつ浅野川 の川水を使って，酒を造ったからというのである。

3）『加賀国菊酒考』には，金沢の町中を流れる屎川 の源流は, 菊水川とか菊潭川といって自然菊が多く, 菊 の露がしたたり落ちたこの川水を, 仕込水として酒を醸 したところから菊酒と称したと記している。

4）『金沢古蹟誌』は犀川を取り上げて,

紙屋九右衛門が家に醸しける酒も古昔から菊酒之呼

て, 犀川の河水を以て造れり

と記している。

鶴来の菊酒の名称由来を裏付けるため, 江戸後期の雑 書に掲げられたこれら 4 つの説話を掲げたが，これらは 菊谷・菊沢・白菊淵・菊水川・菊潭川など，いずれも菊 花の咲き乱れる仙境を水源とした川の水に，深く掛り合 っていることが指摘される4)。しかも，これら説話の原 型は, 古代中国の<菊水の故事>から見出すことができ る。この故事を受けて, 室町後期の歌謡集「䦥哈集」 (『続群書類従』19 輯・下) に,

南陽県の酒のめば 命もいく薬 七百歳をたもちて も龄はもとのごとくなり 
と詠われている。今の人は知らなくても，菊花はこのよ らに延命の効ありと昔の人は固く信じていた。

今一つ無視できないことは，これら説話の舞台となっ た犀川・浅野川・手取川などの源流とい壳ば, 医王山・ 白光山から南へ連らなる白山山系の深い溪谷で, 昔から 薬草の産地として知られていた。したがって, これら説 話の創作には格好の素材が揃っていたわけである。

鶴来の菊酒の名称由来について, 今一つ着目しなけれ ばならないことは, 同奇談の次の記事である。

さて菊といふことは日本には古なきと执もら人多 し,さ海らす゚……(中略) ……伊邪那美の命を菊理 姫とも見ゆれば, こはふるき証拠なり, 菊はくくと 通へばくくり姫と申し奉る也

ここに,「菊」の字をもつ白山比咩神社の祭神, 菊理姫 命が引き合いに出されている。つまりこれらの説話は いずれも古代中国の南陽県の故事に由来しているが，そ の背後には, 白山鮮神社の菊理姫命が深く投影している ことに留意したい。

さらに, 同奇談には,

これをおすへば，此の菊の谷といふ所へ，中々唐の

菊の種を殖うべき汇もあらず, こは自然草なり とある。白山のような深山幽谷にどうして中国渡来の菊 が移植できようか，菊はまぎれもなく本邦固有の植物で ある。したがって, 白山川の菊谷の存在は確実であると 強調している。な拉また，

たまたま歌に, 古くは菊の花見光ねば, 夫れょり後 さまざまと説をなせるなるべし

と, 同奇談に見学る。歌, つまり『万葉集』に䔫の花の 歌が 1 首もなかったからといって, 菊の本邦固有説を否 定すべきではない, と同奇談は重㸚て強調している。ま さに語るに落ちたといわざるをえない。

といらのは, 菊は中国大陸原産で, 本邦への渡来は奈 良時代以降とするのが植物学者らの定説である。とすれ ば, 同奇談の「つるぎの菊酒」についての名称由来説は 作為的で, 信憑性の低い説話とい光よう。といって, 鶴 来が菊酒の発生地の1つであったことを否定する積りは ない。

なお，これまでの考察から推理されるように，〈加賀 の菊酒>の生産地とい党ば, 室町後期は鶴来と宮越, 江戸 後期は金沢であった。しかし，いずれの場合もその「濫 䈓は詳かならず」といら洁かはないであろう。

加賀の菊酒造りで大切なことは, 仕込水の清洌さであ った。室町後期の『新撰類聚往来・下』に, 加賀国は,

酢嚂酒漿水久澄

と特記されているが，宮越の菊酒が、下に名声を馳せた のも, 酒造技術的には「久澄」む水質の故であったと思
われる。『周遊奇談』の「つるきの菊酒」も当然この系 譜に連らなるはずである。

\section{2 近世酒屋之関係深い神社}

\subsection{1 丸山神社}

大分駅からは, 国道 210 号を南下して上芹で左折, 国 道 442 号線を七瀬川沿い儿野津原町役場までは $14 \mathrm{~km}$, さらに矢, 原で国道と分れ，かって細川候の参勤交代の 宿場町, 今市本町まではなお $13 \mathrm{~km}$ ある。今も石畳を 残与街道の三叉路に突き当って左手に, 䌉蒼たる老杉に 囲まれた小台地がある。旧村社丸山神社は, 大分県大分 郡野津原町今市の北端，この小さな台地上に鎮座する。

当社は由緒札によれば, 1610 (慶長15) 年ころ, 加藤 清正が营原道䈯を祀り天満社を創立したが，1663（寛文 3 ) 年, 今市の庄屋佐藤三吾兵衛が領主, 岡藩中川秀成 に請願, 社地若干を賜わり社殿を造営, 直入郡城原八幡 社より针請し丸山八幡社と称した。1869（明治 2) 年, 村内諸社を合祀して丸山神社と改称した。したがって, 祭神は, 八幡社の応神天皇・神功皇后・景行天皇・仲哀 天皇, 天満社の菅原道真, それ飞大歳命 - 大己貴命 - 大 山祇命・高䨝命・稲倉魂命などを合祀する。

大分市郊外飞, 江戸中期の酒造り風景を模した素晴し い彫刻があるから, といら西日本䤁界新聞の工藤隆社長 からの拈誘いに応して, 八鹿酒造(株)の麻生社長, 大分 署の方々と共に当社を訪れたのは, 豊後路の桜花が散り 始めた昭和 57 年 3 月 31 日, 快晴の日であった。

美しい神杉の老樹を背にして, 急な長い石段が楼門に 導びく。土地の人々がく日暮しの門〉と自慢する楼門は 総ケヤキ造り，銅板莫の二層壁である。天井は十二支の 動物, 中国の二十四孝の人物などの彫刻である。目的の 酒造り工程の精巧な浮き彫り細工は, 楼門の最下層の四 方の欄岿に組み込まれている。懐中電登の淡い光で見る と, 酒造米の買入れ，3本杵による精米，熟成もろみの 上槽, 蔵内での計り売り, 酒粕の物々交換, 帳場など, 登場人物の表情を見事なタッチで捕光ている。

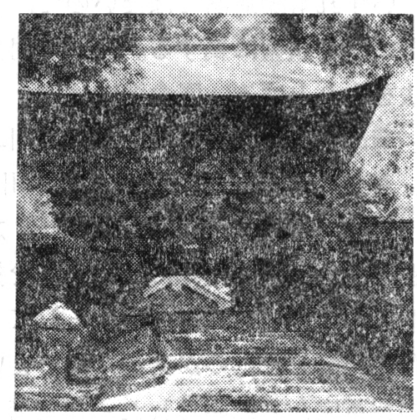

写真 6.3 丸山神社 (日暮しの門) 
この楼門は, 1720 (享保 5 ) 年, 今市の豪商, 小倉屋 の松田庄右衛門の寄進によって建立されたことが, 神殿 に奉納されている「由緒札」から確認できた。またこの 工事は, 府中 (現, 大分市) 古国府の宮大工矢野権左衛 門であったことが,『野津原町史』（未刊行・原稿）の 「今市地区」の条から知ることがでさた。

ケヤキは虫に強いといわれているが，それにしても， 今日でさえ氏子数 98 世帯に過ぎないのに, 1720 年以来 よくもこれだけの文化遺産を保存してきたものである。 よく見ると, 欄間はひずみ, 彫刻が損耗しているのが明 らかに見える。既報らでも強調したように, 今にして保 存対策の手を打たねば損耗するのは時間の問題だし，ま たこれだけの文化遺産の保存方をわずかな氏子に押し付 けるのは酷であろう。県なり国で援助の手を差し延べる ベきである。

当社の取材に当って便宜を計っていただいた西日本醉 界新聞の工藤隆社長, 野津原町役場の森永忠義課長, 当 社の責任者伊藤年彦氏らに改めて深謝すると共に, 彼ら の願い通りに, 一日も早く県なり国の援助がなされるよ らに願いたいものである。

\subsection{2 神田神社}

中央線打茶の水駅から聖橋を渡って北東へ $0.3 \mathrm{~km}$, 旧府社神田神社は, 大已貴命・少彦名命の 2 柱を祭神と して奉斎し，東京都千代田区外神田 2 丁目に鎮座する。 当社については, 江戸末期の地誌, 詹藤幸雄・幸孝・幸 成の『江戸名所図会』（巻 5 ）の「神田大明神の社」条 に,

聖堂の北にあり，唯一にして江戸総鎮守と称す

祭袖 大已貴命・平親王将門の霊 二坐 とあって, 往時少彦名命は当社には斎邧されていなかっ たことが分かったっこの点について，さらに同条に，

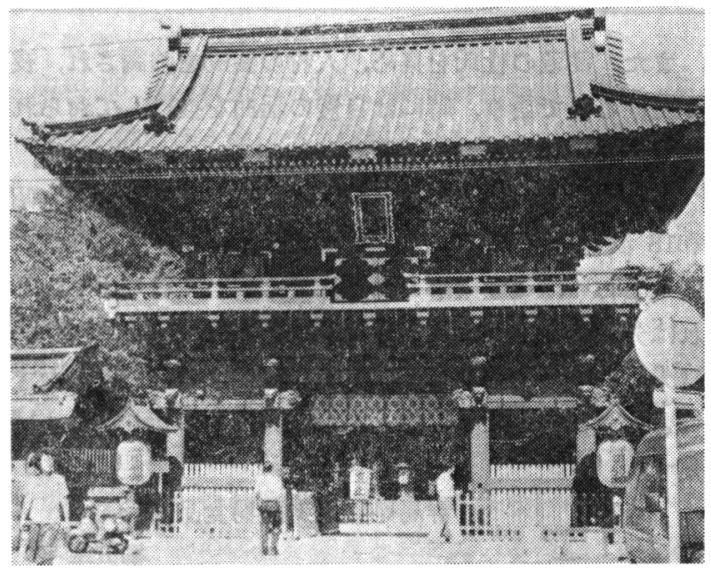

写真 6.4 神田神社
社伝に日く, 人皇四十五代聖武天皇の御宇, 天平二 (730) 年の鎮座にして, そのはじめ柴崎村に(その 旧地神田橋御門の内 (現, 千代田区大手町) にあり) あり し頃, 中古荒廃し既に神燈絶えなんとせしを, 遊行 上人第二世真教坊, 東国遊化の砌ここに至り, 将 門の霊を合せて二座とし，社の傍に一宇の草庵をむ すび, 芝崎道場と号す(今の浅草日輪寺これなり) とあるので確実である。

な扣, 朱塗・重層流造りの随神門の左側の立札「由緒 書」によれば，祭神平将門命は 1309 (延慶 2) 年合祀 と記され, 『神田明神要略』の「摂末社・将門社」条に,

平将門公を祀る, 大正十二年震荻により焼失のため 爾来本殿内に合祀……本社旧蹟地（千代田区大手町

一丁目) に将門塚現存

と記されている。ついでに, 祭神少彦名命は, 1874 (明 治 7 ) 年, 茨城県大洗 磯前神社加ら勧請, 二の宮とし て合祀したとある。

1603 (慶長 8 ) 年, 当社 は江戸基抎張のため 駿河台 ヘ,さらに 1616 (元和 2 ) 年, 江戸川開さくのために 現社地湯島台に遷座, 将軍秀忠は神領 30 石を寄進し, 武州総社とした。1657 (明暦 3) 年の振袖火事で炎上し たが，1661 (寛文元) 年に造営成り, 霊元天皇からく神 田大明神 $>$ 勅額を下賜された。1703（元禄16）年にも また炎上し, 翌1704 (宝永元) 年に造営した。当社が神 田神社と改称したのは 1872 (明治 5 ) 年であった。

日本三大祭の一つといわれる当社の神田祭は, 前記の 同図会に，次のように記している。

祭礼隔年九月十五日（江府神社の祭礼は, 永田馬場 山王を第一とし，当社これに次ぐ，いすれも公より の沙汰として, 練物・楽車等, 善尽し美尽し町中を

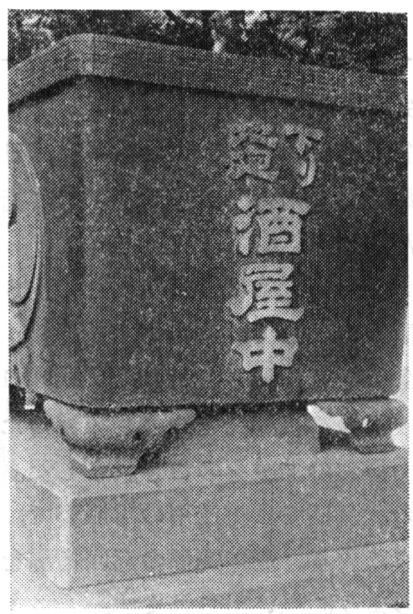

写真 6.5 大 水 盤 (拝殿前) 
引き渡す,これ一時の荘厳なり, この日都下の貴賤 栈敷をかけて見物す) 神事能(隔年九月十五日祭礼 の後十六日に興行す, 神前に舞台をしつらひ, 江府 の町中より棧敷をかけて見物す……) (同条)

氏子は神田・日本橋・楼町・下谷各区 188 カ町に及ん でいたが，今日は町名改正などで氏子町会 108，氏子戸 数は 1 万 5,000 といわれている。

当社で最も興味を引かれたのは, 拝殿前の両脇に置か れた大水盤である。といらのは, この大水盤は「弘化四 丁未 (1847) 歳九月吉日」に, 「下り地廻酒屋中」が寄進 したもので, そのメンバーは

$\begin{array}{lll}\text { 世話人 } & \text { 北新川 } & \text { 松兼店和助 } \\ & \text { 茅場町 } & \text { 小惣店伊兵衛 } \\ & \text { 南新川 } & \text { 鹿利店由兵衛 } \\ & \text { 鎌倉河岸 } & \text { 干1 店政次郎 } \\ & \text { 筋違外 } & \text { 鈴木店新助 } \\ & \text { 願 } \\ & \text { 摂州灘大石 } & \text { 松屋店内一同 } \\ & \text { 筋違外 } & \text { 鈴木新兵衛 }\end{array}$

などと肉太文字で陽刻されている。彼らは, 江戸末期, 江戸府内の下り酒・地廻り酒問屋センターともいらべ き, 今日の中央区新川 $1 \sim 2$ 丁目, 茅場町 $1 \sim 2$ 丁目あ たりの有カメンバーであろら。
さらに，水盤の土台石は設置当時のものではなく，お そらく後代補強したものと思われるが，

$\begin{array}{ll}\text { 神田旅籠町 } & \text { 一木商店 } \\ \text { 神田橋外 } & \text { 豊島屋 } \\ \text { 南新川 } & \text { 鹿 利 }\end{array}$

など，酒屋の名も見られる。当社の一の宮の祭神大己貴 命は, 国土の開拓, 産業の進展, 医薬の伝授ばかりか, 既報句したように，明らかに酒神である。したがって， 下り酒・地趈り酒問屋らが本社に水盤を寄進したのは, きわめて意義の深いことであった。

\section{参考文 献}

1）渡辺昭五：『田植歌謡之儀礼の研究』p. 509〜 512, 三弥井書店 (昭 48)

2）下出積与:『石川県の 歴史』p. 106 107，山川出 版社 (昭 45)

3）小野晃幏 : 『日本産業史の研究』p. 163〜164, 184, 至文堂 (昭 16)

4）加藤百一：「加賀の菊酒」醸協，71（9）701（昭 51）

5）加藤百一：「ケヤキの浮郕り・江戸中期の酒造り 作業」䤑協 77(6) 385 (昭 57)

6）加藤百一:「酒神 と神社 (3)」醸協 76 (12) 800 (昭 56)

\section{訃 報}

\section{稲垣敏郎先生を低ぶ}

稲垣敏郎先生とは, 私が昭和 23 年群馬県醽造試験場 に勤務して以来, 上司として醽造関係のご指導を賜わっ て打りました。

先生は, 大阪高等工業学校醽造科を大正 8 年にご卒業 され, 酒造技術者として, 大藏省, 新潟県, 千葉県そし て山梨県の各県をご指導されたのち, 昭和 12 年から群 馬県醸造試験場の初代場長となり, 業界のために卓越し たご指導で，多大の功績をのこされました。先生の思い 出は, 戦後の混乱期で, 将校用の軍服姿で, ピカピカに 磨いた自転車に乗り, 酒造関係の巡回指導をされていた 勇姿が昨日のように思い出されます。
また，酒蔵の杜氏を集め，人材の養成を強調され，夜 の更けるまで語り，時には自慢の話曲を披露しておられ たことも記憶しております。

さらに, 先生は酒の品質向上・安定を第一飞考兄, 昭 和18 酒造年度から，清酒酵母の製造および共同酒母の 製造を行い，この大事業は現在でも続いております。こ れは先生の残された大きな業績であります。ここに私達 は先生のご遗志を継承して業界発展のため努力をいたす ことを拉いいたし，謹しんでご冥福をお祈り申し上げ ます。

\section{群馬県醅造試験場食品部長}

柳沢羊平 